\title{
Fractured Lives, Splintered Knowledge: Making Criminological Sense of the January, 2015 Terrorist Attacks in Paris
}

\author{
Sandra Walklate ${ }^{1} \cdot$ Gabe Mythen $^{1}$
}

Published online: 4 April 2016

(C) The Author(s) 2016. This article is published with open access at Springerlink.com

\begin{abstract}
Cottee (Br J Criminol 54(6):981-1001, 2014) makes the case that criminology has much to contribute to an understanding of theistic violence. However the 'hubris of positivism' (Young in The criminological imagination, Polity, Cambridge, 2011) curtails the criminological imagination and this is particularly evident in the debates that permeate contemporary understandings of religious extremism and radicalisation. Using the terrorist attacks in France 2015 as a touchstone, this paper explores the current state of criminological engagement with these issues. First a synopsis of orthodox current criminological talk about religious extremism and violent crime is considered. Next a critical analysis of the events in Paris based around what is 'known' about them is offered in the light of this knowledge. Finally, drawing on the work of Young (2011) the implications of this analysis for criminology are considered resulting in a refinement of the biases identified by Cottee (2014).
\end{abstract}

\section{Introduction}

If the terrorist attacks in the United States in September 2001 marked a moment of 'anthropological shock' in the Western world (Beck 2015: 77), events in Paris in January 2015 served to reconfirm that $9 / 11$ was more than simply a 'transgressive moment' (Jenks 2003). The Paris events attracted the media gaze for several days and unfolded in real time across international broadcast networks. On January 7th two gunmen entered the Paris offices of the French satirical magazine Charlie Hebdo, killing nine people inside those offices and a police officer attending the incident. The perpetrators claimed that the attack

Sandra Walklate

S.L.Walklate@liverpool.ac.uk

Gabe Mythen

G.Mythen@liv.ac.uk

1 Department of Sociology, Social Policy and Criminology, Eleanor Rathbone Building, University of Liverpool, Bedford Street South, Liverpool L69 7ZA, UK 
was carried out to avenge the Prophet Mohammed for the magazine's derogatory portrayal of Islam and Muslims. The next day a policewoman was killed by a third gunman who, on January 9th entered a kosher supermarket in Paris taking several people hostage. Four people were killed inside the supermarket. The three gunmen were all eventually shot dead by the French security services. The total death toll came to seventeen. A death toll superceded in the attacks that took place in this same city in November 2015, which claimed the lives of 133 people. Aside from re-igniting debates about the threat of 'homegrown terrorism' in media, political, and security circles, both of these events have had a profound effect in France and elsewhere. For some, the attacks in Paris may well have constituted a 'moral violation' (Beck 2015: 77), leading to millions of people in January 2015 collectively rallying around the slogan 'Je Suis Charlie' (see Khan and Mythen 2015). For others, the focus on free speech at all costs and the intensification of surveillance on Muslims which followed generated disquiet (see Fassin 2016). Thus, the happenings in Paris raise a series of complex and knotty issues that stretch beyond concerns about the execution of violence inspired by religious and political ideology. Extensive media coverage of the events in January coupled to widespread discussion of the life biographies of the perpetrators-which did not happen to the same extent in respect of the November 2015 perpetrators-affords a unique opportunity to reflect on the contemporary criminological response to events such as these.

In 2014 Cottee accused those working within criminology of three biases: the secular, the religious and the liberal. He avers that a focus on the secular reflects a domain assumption of the discipline and goes on to suggests that whilst this has resulted in work on the crime prevention aspects of religion, there is much less concern with the crime inducing aspects. For Cottee (2014) each of these biases constrain the criminological vision and mute its capacity to make sense of theistic violence. Cottee (2014) suggests that it is high time that we talked about such things. Of course, this might be taken to imply that criminology and criminologists do not talk about such things. They do, and, to be fair, Cottee acknowledges this. What is more prescient perhaps is that this talk tends to take a particular shape and conforms to a particular agenda. Our objective here is to try and push Cottee's critique further and to reflect upon how it might be possible to engage in a different and more productive conversation about religious extremism and its connection to violence within criminology. In order to do this, the paper falls into three parts. First, we offer a critical criminological analysis of the events in Paris in January 2015 based around what is 'known' about them and available in the public domain. Second, we provide a synopsis of orthodox current criminological thinking about religious extremism and violent crime and seek to establish the fit between this and these events. Bringing these two elements together provides a platform for developing a differently nuanced agenda for thinking through the problem of religious extremism. Third, in the light of the preceding discussion, we attempt to refine the biases identified by Cottee (2014).

\section{Fractured Lives: Said Kouachi, Cherif Kouachi and Amedy Coulibaly}

In the light of the coverage given to the perpetrators of the January attacks, it is possible to piece together aspects of the life histories of the three men involved: Said Kouachi, Cherif Kouachi and Amedy Coulibaly. Of course, it would be naïve to presume that the motivations for their actions can be deciphered from these secondary accounts, or even that such accounts enable us to pinpoint, retrospectively, the defining moments in their life 
histories. Rather, the purpose here is to create loosely pixilated portraits of these three men in order to reflect upon the potential efficacy of the available criminological approaches to make sense of them. Thus, it is the patterns articulated in these young men's lives that are more pertinent to our argument, not the explicit veracity of the details.

Cherif and Said Kouachi were both born in Paris and were French nationals of Algerian descent. Little is known about their father, but their mother died of a drugs overdose. The two brothers are said to have returned home from School to find her, lying dead in their apartment (Irish Times 2015). The elder brother by 2 years, Said's life seems to have provoked the least comment either in relation to his childhood or in terms of his relationship with his brother. Said was registered as unemployed and had been living with his wife and two children in a two bedroomed apartment in a social housing tower block in the Croix Rouge area of Reims, one of the poorest and rundown parts of the city. His neighbours observed that he was a 'quiet and private' person, who wore traditional Muslim clothes (Chrisafis 2015). He was the only one of the three perpetrators not to have spent time in prison, although he had come to the attention of the police in 2005 as a result of an investigation into a suspected radical Islamist group (Chrisafis 2015). Prior to 2005, he had cohabited with his brother in the 19th arrondissement of Paris, but, unlike his brother, he was not convicted on terrorism charges linked to the so called 'Buttes-Chaumont cell' (Chrisafis 2015). After the Paris attacks, the Yemeni authorities confirmed that Said was in Yemen for a period of several months in 2011 and was suspected of having fought for alQaida in the Yemen. He is thought to have been amongst a group of foreigners deported from Yemen in 2012 (Chrisafis 2015). Both he and Cherif were on the US and UK security intelligence no-fly lists (BBC News 2015).

Said's brother, Cherif was born on 29th November 1982 in the 10th arrondissement of Paris and, after his mother's death, was raised in care homes in Brittany from the age of 12 . Much more seems to have been made public about the life of Cherif Kouachi than of his brother. Cherif is said to have had a poor educational record, but went on to pursue a sports qualification, later becoming a gym instructor (BBC News 2015). On moving back to Paris in 1988 he lived in the 19th arrondissement to the north of the city and held a number of low skilled, low paid jobs, latterly working as a pizza delivery driver. Documentary footage of Cherif retrieved from a 2004 TV program shows him dancing to rap music whilst wearing a backwards baseball cap. He claims in the documentary to have become radicalized stating 'It's written in the texts that it's good to die as a martyr' (Chrisafis 2015). By 2005, Cherif had become involved in a group seeking to channel young Parisian men to fight in Iraq. It became known as the Buttes-Chaumont cell named after the Park where Kouachi and others met and exercised together (Chrisafis 2015). In 2005 he was detained whilst attempting to board a flight bound for Syria—at that time the main gateway for jihadists joining militants fighting US troops in Iraq-as part of the same investigation that had brought Saif to the attention of the police. By this time he had reputedly come under the influence of a radical preacher, Farid Benyettou. At the trial his lawyer presented him as somewhat relieved to have been arrested claiming that he was simply looking for excitement (Chrisafis 2015). At the end of his trial in 2008 the court sentenced him to 3 years which meant he was released immediately having already spent almost that much time in prison on remand. After the case this lawyer is said to have told the media that he had 'found a kind of family, a cause in life' (Chrisafis 2015). His time in prison was spent in the largest prison in France, Fleury-Merogis on the outskirts of Paris, which at that time had been subjected to public criticism about unhygienic conditions and over-crowding of inmates (Alexander 2015). He met Amedi Coulibaly in Fleury-Merogis. On release from prison, Cherif maintained a low profile, became married and took up employment in the 
fish section of a supermarket in Paris. In 2010 he was again arrested by police, this time as part of an alleged plot to free Smaïn Aït Ali Belkacem, an Algerian born Islamist, who had been sentenced to life imprisonment in 2002 for his part in the bombings at the Musee d'Orsay train station in Paris in October 1995. Having refused to respond to any questions from the police he was subsequently released without charges.

Aged 32 years old, Amedy Coulibaly was born in Juvisy-sur-Orge on the outskirts of Paris, his parents having migrated to France from Mali. The only boy in a family with nine sisters, he grew up on a large housing estate, Le Grande-Borne, a neighbourhood of Grigny, 14 miles south of Paris (Irish Times 2015). This estate was one of the trouble spots of the 'banlieues' that flared up in 2005 and one routinely characterised in the media as a centre for drugs and violent crime. Coulibaly was convicted twice for armed robbery. In 2000, when he was 18 years old, his closest friend, Ali Rezgui was shot dead by the police while attempting to flee the scene of a robbery. The French courts subsequently rejected requests by the victim's family to review the circumstances of the death, ruling that the officer acted in legitimate defence. Indeed, it was this decision not to review the incident that is said to have triggered several days of rioting in Grigny and other banlieues on the Southern outskirts of Paris (Meichtry 2015). After serving his first prison sentence for armed robbery, he began dealing drugs and was convicted, serving another sentence. When Coulibaly was serving his third prison sentence for armed robbery he and Cherif Kouachi met in prison. Coulibaly was one of the inmates who had participated in campaigning against the conditions in Fleury-Merogis. He and Cherif Kouachi not only became friends, they found a mentor in Djamel Beghal, an associate of Abu Hamza and Abu Qatada. After leaving prison, there is evidence to suggest that Coulibaly and Kouachi maintained contact with Beghal, visiting him whilst he was under house arrest in rural France (BBC News 2015). In July 2009, Amedy Coulibaly married Hayat Boumeddiene in an Islamic ceremony conducted at the home of Mr. Coulibaly's parents. As Boumeddiene was not present at the wedding, the marriage was not recognized under French law (Meichtry 2015). Along with Cherif Kouachi, Coulibaly was accused of being involved in a plot to free Smaïn Aït Ali Belkacem from prison in 2010 (Irish Times 2015). The case against Kouachi was dropped, Coulibaly received a 5-year prison sentence, a police search having found AK-47 ammunition stored in a paint pot in his apartment. While serving his term in prison Coulibaly received the news that his father was dying of cancer. He submitted a request for temporary release to visit his father which was denied (Meichtry 2015). He was released in 2014, described as a model inmate (Chrisafis 2015), and resumed married life with Hayat Boumeddiene. She left France for Syria a few days before the attacks in Paris and was in close contact with Said Kouachi's wife in the months prior to the attack. In a video made before his final act, he claimed that his assault was justified as a reprisal for Western attacks on Islamic State militants.

Although incomplete, partial and contingent on secondary sources, these accounts are illustrative of the fractured lives referred to in the title of this paper. In many ways these lives reflect different features of well-established knowledge within criminology addressing routes into crime: alienation, exclusion, family size, poverty, disrupted upbringings, pathways from home to care and from crime to prison, struggles within the education system. All of these factors have been identified as 'predictors' of criminal behaviour. Moreover, as Braithwaite (1989) pointed out some time ago, being young and male is one of the major factors that any criminological theory needs to account for in explaining crime. These young men, as we shall see, also grew up in areas classified and policed as problem crime areas: socially deprived, suffering from high unemployment, highly densely populated- housing largely immigrant populations. All of which point to the 
relevance of structural conditions. To what extent are these lives captured by contemporary ways of thinking about routes into violent extremism within criminology?

\section{Three French Men: Criminology and Violent Extremism}

This is not the place to review all the available criminological work that has focused on the relationship between religion and crime (see Akers 2010). Cottee (2014) argues that much of this work has focused on the deterrent effects of religious belief on potential deviant and/or criminal behaviour: a view tempered recently by Tivalli et al. (2013). However this relationship is rendered more complex when religious belief is seen to encourage violent action, particularly when such actions are deemed to be replete with transcendental rewards (Routledge and Arndt 2008) and interpreted as separate and separable from the contemporary context (Bielefeldt 2015). Against this general backcloth, and as Cottee (2014) himself argues, understandings of the role of belief/religion per se in all its complexity in promoting violent extremism have been decidedly muted. Nonetheless it is possible to discern four main approaches to this issue: the 'lone wolf' approach, strain theory, subcultural approaches, and those that take adopt a structural perspective. The question remains, what might each of these approaches reveal to us about the three young men that carried out the attacks in Paris in January 2015?

As the label implies, the 'lone wolf' approach looks to make sense of violent extremism as it might be generated by the innate characteristics of the individual concerned. Much has been made of the personality of Anders Breivik that fits well with this kind of understanding (see, inter alia, Billig and Stalne 2012). Gruenewald et al. (2013) have pointed to the significance of mental instability/illness, military background, age, and relationship status as distinguishing 'loners' from other kinds of extremists: a product of what they call 'self-radicalisation'. In a similar vein, Bhui et al. (2014) report a link between mild depression and expressed support for violence and tendencies towards radicalisation. However, as Pape (2006) argues, it is important to remember that the vast majority of suicide bombers also belong to, or are affiliated with, organizations making the attribution of psychological factors alone difficult. Were these French men 'lone wolves'?

Arguably, one of the three men, Coulibaly, was disposed toward the thrill of violence, with a long history of injurious offences and identified as suffering psychological problems in his youth. Coulibaly was first accused of robbery at the age of 15 and went on to develop a criminal career that included shoplifting, drug-dealing, armed robbery and the sale of stolen goods (Meichtry 2015). A psychiatric report on Coulibaly submitted as court evidence is said to have found no evident pathology, but an 'immature and psychopathic personality', with 'poor powers of introspection' and a desire to be 'all powerful' (BBC News 2015). However, whatever weight is afforded to these observations neither he, nor Saif or Cherif Kouachi can adequately be categorised as 'lone wolves'. In terms of the role of religion in contributing toward their actions, it is likely that Coulibaly and Cherif Kouachi became more devout during their time in prison, although it remains an open question as to whether or not this is where they became 'radicalised'. Of course, the 'lone wolf' approach, in focusing on innate characteristics or problem personalities, draws attention away from the structural conditions in which these young men found themselves and the role of their beliefs in seeking a way of managing those conditions. In Coulibaly's case it seems reasonable to suggest that his hatred of the French authorities was at least in part motivated by the perceived injustices he, his family and his friends, had been subjected to. 
Those working with strain theory draw together psychological approaches with the sociological. Agnew (2010) has recently developed this approach and applied it to routes into violent extremism. He argues that 'collective strains' have a high impact on individuals, when they are seen to be unjust, and when they are seen to be the result of powerful others 'with whom the members of the strained collective have weak ties' (Agnew 2010: 136). Under these conditions those individuals with a psychological propensity for violent extremism will be particularly vulnerable to engaging in that kind of action. Indeed, as is developed below, Cherif Kouachi, referred to himself as a 'ghetto Muslim' in an earlier police interview, more than hinting at an awareness of his own structural location and the strains inherent within it. Indeed, the vignettes of each of their lives effectively illustrate the kinds of 'strains' they lived with. However, as DalgaardNielsen (2010: 801), and others have asked, why do some people react different with violence as others not when all are exposed to the same conditions of strain? This rhetorical question succinctly reminds us of the role of belief and the different ways in which belief might be expressed. Put simply not all those who find themselves cast as 'ghetto Muslims' choose to show their allegiance to the Prophet in the dramatic way that these three young men did.

The question posed by Dalgaard-Nielsen (2010) has led some to consider the relevance of a variation of strain theory focusing in on the significance of sub-cultural values. Here attention has been drawn to the 'culture of violence thesis' (see Mullins and Young 2012). In this vein, Cottee (2011) considered the importance of both 'sub-cultural style' and structure in understanding the commitment to Jihadism. This approach accents the importance of social networks, personal bonds, and the construction of shared meanings and understandings about the world. In so doing, it offers a valuable additional contextual dimension to Sageman's (2007) observation that individuals who join radical Islamist groups committed to violence are already acquainted with an existing member of the group. Moreover, the importance of networks in promoting and/or undermining violence has also been noted in the context of what Hamm (2009) refers to as 'prison Islam'. Here again we can see aspects of this approach present in these young men's lives. Their experience in prison-developed below-is worth noting in particular, as are the prior inter-connections between them leading up to the events in January 2015. Yet again caution is advisable here. Subcultural processes do not exist in a vacuum. They cannot but be formed in a structural context.

In structural explanations, social exclusion and disenfranchisement lead to the emergence of extremist violent subcultures. Yet the question remains as to whether or not violent extremism can be explained solely by the recourse to poverty, inequality and exclusion. For example, Kreuger and Maleckova (2003) note, the vast majority of materially and geographically dispossessed Palestinians do not engage in political violence. Similarly, the impoverished and persecuted Rohingya Muslims of Myanmar fled en masse under persecution rather than responded with force. Moreover, the explanatory power of structural perspectives is also thrown into doubt by the inchoate 'profiles' of perpetrators of terrorist attacks. Aside from the obvious case of the Saudi millionaire who became the leader of Al Qaeda, there are numerous examples of individuals from non-deprived backgrounds engaging in violent extremism (see Post 2007), including Anders Breivik and the so called 'Hamburg cell' who executed the 9/11 attacks. These examples suggest it is erroneous to presume that material deprivation works in a simple and/or straightforward manner in relation to the propensity to commit violence. Indeed, in terms of the three young men under discussion here, whilst they all lived in relatively poor suburbs and had experiences of deprivation in their early lives, those experiences were not all negative. One 
of them, Amedy Coulibaly, on release from prison in 2007 went on to work for Pepsi Cola and was once received-along with nine other young guests-at the Élysée Palace in 2009 by former president Nicolas Sarkozy at an event on youth employment (see Irish Times 2015; Meichtry 2015). Saif Kouachi was employed for a time by the City Hall in Paris as a 'recycling ambassador' (Beaud 2015)- illustrative of not only the limits of structural explanations on their own but also the uneven nature of these young men's lives.

To summarize; there are a number of different explanations available to criminologists with which to make sense of what may motivate people to engage in violent extremism. While we have, for analytical purposes, mapped them out as distinct, it may be prudent to view them as potentially complementary. Nonetheless, it is certainly the case that they are each concerned with different levels of analysis - from the individual, to the cultural to the structural. Schmid (2013) uses a similarly layered analysis of available understandings of radicalisation: the micro, the meso and the macro. Arguably, the criminological approaches highlighted above address the micro and meso levels, but fail adequately to deal with the macro. Whilst it is likely that a multi causal approach is appropriate, the four explanatory strands discussed here share in common a muting of the role of religious belief. They also erase the biographical experiences of perpetrators of violent extremism. The third feature they share in common is a muting of the role of the State in both its domestic and international actions (Schmid 2013). So, it is important not only to piece together a picture of these young men's lives but also to put those lives into a particular socio-cultural context in order to dig a little deeper into making sense of their final acts of violence.

\section{From 'Ghetto Muslims' to 'Soldiers of the Caliphate': Strangers Within?}

It is clear that the range of life choices open to the three young men were both conditioned and limited by ethnicity, class and circumstance. As noted above, when arrested as he attempted to travel to Iraq, Cherif Kouachi referred to himself during a police interview as a 'ghetto Muslim'. The word 'ghetto', though considered derogatory in many international contexts, is used in France as a coda for describing particularly deprived areas with large, ethnic minority populations. All three perpetrators were born, grew up, and lived in such areas. Understanding this feature of their lives sets the scene for appreciating how their attitudes towards, and relationship with, the French State was framed.

In France, the frequency of police checks of young, ethnic minority males has provoked similar frustrations to those voiced in Britain and elsewhere. As Camilleri (2012: 34) notes:

To explain why descendants of immigrants of Muslim origin have a distinct mistrust for the police, it is necessary to take into account the frequency of contact these people have with the police force, especially in the form of police identity checks. Such identity checks have long been a source of controversy among young people from working class backgrounds, especially those of immigrant origin. Indeed, a 2009 OSI study based on in situ observations of such identity checks in Paris established that police controls often targeted young men that visibly belonged to ethnic minorities and who adopted "youth" dress codes.

The ethnographic work of Fassin (2013), conducted during the disturbances in Paris and elsewhere in 2005 and published in English in 2013, stands as testimony to the ordinary, everyday, normalised nature of these checks and the types of attitudes and experiences that accompany them for those so treated. In the context of the kind of criminal behaviour 
under discussion here, Body-Gendrot (2012: 90) adds that a range of criteria are used by the security and intelligence services to designate an area a 'sensitive zone'. These include the density of the immigrant population, the presence of ethnic shops, non-Western and religious ways of dressing and the presence of radical imams. She goes on to comment: 'this is a quite a feat for a country that does not officially recognise ethnicity and denies racial profiling' (ibid). Thus young, ethnic minority males, particularly in sensitive zones, live their lives under something of a microscope, being frequently asked to produce their papers and to justify what they are doing and why. Such structural conditions are not just about the intensification of surveillance and modes of policing, however.

Hedges (2015), reflecting on spending time in the housing projects (the 'banlieues') states:

There is little employment in these pockets of squalor. Racism is overt. Despair is rampant, especially for men, who feel they have no purpose. Harassment of immigrants, usually done by the police during identity checks, is almost constant ... French Muslims make up 60 to 70 per cent of the prison population in France. Drugs and alcohol beckon like sirens to blunt the pain of poor Muslim communities. The 5 million North Africans in France are not considered French by the French.

Herein lie some deeper clues to the kinds of currents affecting the lives of Coulibaily and the Kouachi brothers. Historically, having an address from one of the banlieues constituted an automatic disqualification for some employers in the job application process (Murray 2006). Further, as Body-Gendrot (2010: 657) observes, a lack of commitment by policymakers and the police alike to these neighbourhoods in terms of developing responsive infrastructures and effective service delivery is an important factor in understanding the conditions in the banlieues. She also reports that unemployment rates in some areas peak as high as $64 \%$ for juveniles and immigrants (based on 2008 figures, ibid: 659) and poverty rates are three times higher in these areas than the national average. Thus, it is easy to see how routes into criminality become not some much possible avenues, but routine roads taken. Then there is prison.

The general conditions and standards in French prisons fall short of being acceptable on a number of counts. In addition to the high proportion of inmates that identify as MuslimHedges (2015) suggests 60-70\%-reports of older prisons being dilapidated and suffering from infestation are evident from European Prison Observatory Reports (see Cretenot and Liaros 2013). Khrosrokhavar (2013) reports that overcrowding, understaffing, and a high staff turnover have all contributed to the qualitative increase in radicalisation in prison. The small number of prison Imams as compared with Catholic chaplains is also a source of grievance for Muslim prisoners. These conditions-taken together with a variation in institutional interpretations about access to special diets and so forth-add to an institutional denial as to the nature of the French prison population and its needs/rights. In a detailed and nuanced study of radicalisation in prison from the perspective of the prisoners themselves, Khrosrokhavar (2013) contends that whilst the heavy surveillance and supervision practiced in French prisons has prohibited the growth of large, enduring radical Muslim networks in prison, the restrictions on religious practices taken along with other poor services simultaneously facilitates the formation of smaller, more tightly bonded groups. Lying behind some of these issues is the commitment of the French State to 'laicite': secularity.

Under these conditions the possibility of suffering what Spalek (2006) poignantly refers to as 'spirit injury' is tangible; as is the quest to heal such wounds with dramatic and violent reprisal. Indeed, the respective journeys of the Paris trio into violent extremism 
share many parallels with that of Mohammed Merah, a French national of Algerian descent, who shot and killed seven people in Montauban and Toulouse in March 2012. In a detailed biographical account of Merah's life, Andre and Harris-Hogan (2013) document his transition from juvenile delinquent, through to radicalisation in prison, to calling himself a 'Knight of Glory' - a radical Salafist group established in France in 2010 - just before he was shot after being under siege from the police. He, like Saif and Cherif Kouachi and Amedy Coulibaly, found a place and identity at the moment of death through the rewards engendered possible by their religious belief (see also Wiktorowicz 2005). Fassin (2011) might add to this that through the violence they inflicted on others it is possible to trace the violences of the State.

The cumulative effect of documenting the lives of the Paris perpetrators in this way adds some weight to the view that they were strangers in their own country. Not considered French even by the French: strangers within. This liminal life in which immigrants traverse the world, sometimes without papers and sometimes with, bears the traces of French colonial history. As one of the authors of this paper was categorically informed by a French colleague 'our Muslims are not your Muslims'. This may be the case, but through religion 'different Muslims' are spiritually connected by ummatic attachments. As Hedges (2015) observes, the failure to connect the events in Paris with the military conflict engagementthen disengagement - of the West in Iraq and Afghanistan has fuelled anger. This is an anger that is, of course, intrinsically connected with collective despair and poverty-the 'sprit injury'- but it is also an anger that the events in Paris and elsewhere suggest is dangerous to ignore. Moreover in France, the liminality of these lives and the feelings so generated have been afforded an added dimension over the last decade through renewed French commitment to 'laïcité': secularity.

\section{La Republique, Violent Extremism and Criminology: Knowing the Lives of Others?}

Estimating the shape and size of the ethnic minority population in France and its religious composition is difficult, since the collection of such personal data is prohibited. This is one of the consequences of the French commitment to secularity, itself a product of infamous periods of religious and sectarian violence. However, estimates suggest that Islam constitutes the second largest religious faith in France standing at around $10 \%$ (Camilleri 2012). The concept of 'laïcité' was enshrined in French law in 1905, through what is commonly referred to as the Law of Separation. When formulated, the intention of this Law was to ensure that the State and its institutions were free from religious domination or bias. Through this law, religion was deemed a matter of conscience and at the time of its formulation the focus of concern was to ensure freedom for Jewish and Protestant minorities. This separation of church and State, Andre and Harris-Hogan (2013) suggest, has had unintended consequences. In confining religion as a private matter, one of the side effects has been that the State has potentially accumulated greater not lesser coercive power over individuals. In the last decade in particular - a period in which all of the young men discussed above were growing up, a 'hard' version of 'laïcité' has emerged and one that appears to have impacted on some faith communities more than others. Deep concerns over the wearing of headscarves emerged in the late 1980s were followed by the 'debate' about the wearing of the hijab in schools. The prohibition of both of these practices has marked France out as an outlier in comparison to other European nations. As Barras (2013: 
227), suggests 'laïcite' has therefore been mobilized over the last decade as a resource to address this presence (of Muslim minority groups) and justify an increasingly non-accommodating stance vis-a-vis demands made by French Muslims in different spaces'. Arguably the hardening of laïcité in France has taken its toll predominantly on Muslim women, constituting a visible trace of the increasing surveillance and control over Muslim minority lives. Whether male or female, the question of being French and yet not being considered 'French' at all has had real consequences and caused schisms and dilemmas for those whose identities are stigmatised and problematized.

It is important to contextualise this hardening of secularity with reference to dominant values and attitudes. Eurobarometer reports for 2004 as compared with 2014 indicate that, in 2004 French people thought that the three biggest problems in France were unemployment (51\%), crime (27\%), and the economic situation (24\%). However, by 2014 public perceptions of the three biggest social problems had changed to unemployment (63\%), the economic situation (26\%) and immigration (11\%). The rise in public concerns about 'immigration' is likely to be connected to the observations regarding a cultural and religious crunch made by Andre and Harris-Hogan (2013: 317):

The increasing multi-cultural transformation of French society through the influx of non-Christian immigrants who remain attached to their religious rites are in conflict with the customs of Republic life and often do not feel at home in the laïcité's radical separation between private and public spheres.

In their view, this leaves the socially excluded in France, minority Muslim communities susceptible to extremism. They go on to suggest that for Merah-the subject of their case study - this wider context only served to harden his search for a firm identity through religion. The greater intrusion into the private realm permitted by the French commitment to the secular frames some of the problematic features associated with experiences of the criminal justice process. This is particularly the case for those Muslims in prison whose liminal existence in wider French society can be exacerbated through lack of recognition of religious belief in that setting. Commenting on the de-territorialised, global features of Islam that cuts across cultures, Andre and Harris-Hogan (2013: 319) suggest that the challenge for France is to 'promote a genuinely liberal understanding of its neutrality with respect to religious diversity'. Of interest here is their reference to what might count as 'liberal' and it is to that issue and its relationship to the production of criminological knowledge that we shall now turn.

Hopefully the use of the vignettes has illustrated that there are points of resonance between contemporary criminological approaches to violent extremism and the stories with which we have been working. However, returning to our starting point, Cottee (2014: 985) posited that the liberal bias of criminology 'reflects a liberal uneasiness on their part [criminologists] about the current public debate on religion and the highly political and politicised form it has taken'. So whilst there has been considerable concern about the demonization of religious minorities emanating primarily from those on the 'left' of the discipline, it should be noted that there has been at least equal energy concerned to make sense of violent extremism by those committed to a more conventional criminological conceptual agenda. Arguably there is more work to be done from within this agenda through the lens of life course criminology and/or the application of 'turning points' (Sampson and Laub 1993). Indeed, we agree with Cottee (2014) on the need for criminology to pay more attention to theistic violence. However how criminology might proceed to do that demands a more thorough appreciation and critique of the liberal bias within the 
discipline. One place from which to develop such a critique might be to reflect upon that which Young (2011) has called the 'bogus of positivism'.

Young's (2011: 80) critique of positivism is largely directed at the dominance of American criminology on the wider nature and form of the discipline which results in a tangible contradiction, namely that 'the most influential work in criminology stems from one of the most atypical advanced industrial societies'. Notwithstanding interpretations of 'influential', buried in this contradiction is a projection of American (liberal) values particularly concerning individualism on the discipline as a whole. This embrace of positivism embeds those liberal values within criminology and produces a "nomothetic impulse (ibid. 79) that implies a 'denial of specificity' (ibid. 77). This vision of knowledge and its production process denies culture, and facilitates the comfortable and comforting liberal analyses of 'the Other'. While such ways of thinking, 'represents something of a defence against the insecurities of the modern world' (Young 2011: 69) in which we are all implicated. Young (2011) is keen to indicate that not all criminology takes this form, but the dominance of this version of criminology privileges some knowledge forms and renders others less visible. We can see the presence of this version of criminology in the implicatory denial of the need to understand the situated life experiences and biographies of those driven towards violent extremism and to situate those lives with their macro setting.

In our efforts to appreciate the lives of the three men who were motivated towards such extremism in Paris in January, we have sought to make sense of their lives and experiences within the cultural specificity of France and, in so doing, have drawn on material outwith criminology, its claims as a rendezvous subject notwithstanding. This reflects the splintered knowledges referred to in the title of this paper. Echoing both Bell (1979) and Young (2011) our approach refutes single dimensional analyses of what is a complex social and global problem. As Bell (1979) notes, in attempting to understand the cultural contradictions of capitalism: 'religion is the fulcrum'. He poignantly goes on to suggest that, 'a culture (i.e. capitalism) which has become aware of the limits in exploring the mundane will turn, at some point, to the effort to recover the sacred' (Bell 1979: xxviii). Given the contemporary political, policy and social challenges posed by international conflicts and political and religiously motivated violence-this is an interesting observation indeed and one that affords a clue as to how a criminological agenda might be better informed to make sense of such events. It demands more than a loosening of the shackles of 'abstracted empiricism' (Young 2011: 1). It demands revisiting what might constitute criminology's theoretical and conceptual agenda.

\section{Conclusion}

This article has endeavoured to make criminological sense of the lives of others. This has admittedly been an endeavour which has taken place at a distance and conducted with contingent knowledge. Doubtless the 'characteristics' of these offenders have been eagerly inputted into global databases to derive future risk factors and identify those 'vulnerable' to violent extremism. This paper reflects an entirely different and dissonant exercise. We have sought to utilise sketches of the biographies of the three men who committed the attacks in Paris in January 2015 as a vehicle for assessing the utility of criminological knowledge about violent extremism. We have also sought to tease out some of the peculiarities and specificities of the French context and in so doing have drawn attention to the violences of 
the State. So, amidst the clamour to find new explanations to what are perceived to be new problems, structure, context and agency remain square and middle. In as much as it has become popular to explain the attractiveness of violent extremism with reference to the internet propaganda posted on 'jihadi websites' and the persuasive ideational role played by mysterious mullahs, the problem of violent extremism truly does need appreciating in the round. It is a phenomenon with micro, meso and macro features (Schmid 2013). So, any understanding must include the 'old' factors that we know go in the mix when explaining violent crime. However, given the nature of violent extremism, those 'old' factors must also include the role of the state both domestically and internationally. Thus, there remains a need to broaden out the criminological focus on moral violations from violent crimes of individuals to the systemic violence perpetrated by States and corporations through reckless military forays and negligent practices. Elsewhere it has been argued that in order for criminology to avoid becoming a 'zombie discipline' it is time to reflect on a re-orientation of its focus so that economic power relations and embedded cultural factors become much more central to the pre-occupations of the discipline (see Walklate and Mythen 2015). Such a shift in priorities would require an embrace of ambiguous and messy situations and processes that do not have visible or concrete 'solutions' and that we appreciate our responsibilities and role in the production of knowledge about those processes.

Of course, some continuities remain. It is no coincidence that old fashioned 'police property' (Lee 1981) invariably includes the young, the unemployed and those from ethnic minority groups alongside the undisputable evidence that the work of the state on ethnic minorities in France and elsewhere needs to be in any framework of analysis. Indeed:

There is a symmetrical relationship between those least likely to be pre-occupied with the liquid anxieties of the age-since their pre-occupations have always been with work, food and shelter-and those most likely to be the targets of institutional pre-occupations, since they constitute the other, the wasted, those to be feared (Walklate and Mythen 2015: 183).

In this respect, there is some similarity here between this analysis and that offered by Hallsworth and Lea (2011). However, the processes underpinning this symmetrical and symbiotic relationship are, as Wacquant (2009) suggests, doubly political. They are a product of institutional actors and rest on a presumption that 'we have a life in common'. The problem is that liberal democracy, and its contemporary iteration in the form of neoliberalism, denies us a life in common. Hence, for some the search for the existential (religion) constitutes what, in Bauman's (2006) terms, may constitute their biographical solution to systemic problems. Criminology does have the capacity to speak out on these issues. Its silence, post the events in France throughout 2015, speaks in a fundamental way about its current neglect of the issues with which this paper has been concerned. In this silence the profundity of criminology's liberal bias is to be found. In the absence of challenging this bias, the discipline is constrained by splintered knowledges and its capacity to truly understand fractured lives remains impaired.

Acknowledgments An earlier version of this paper was presented at the Institute of Criminology, Sydney, June 2015, and at the European Criminology Conference, Porto, September, 2015. The authors would like to acknowledge colleagues who gave feedback on both of these occasions and also express sincere thanks for the thoughtful comments of the anonymous reviewers. The faults that remain are, as ever, our own.

\section{Compliance with Ethical Standards}

Conflict of interest The authors declare that they have no conflict of interest. 
Open Access This article is distributed under the terms of the Creative Commons Attribution 4.0 International License (http://creativecommons.org/licenses/by/4.0/), which permits unrestricted use, distribution, and reproduction in any medium, provided you give appropriate credit to the original author(s) and the source, provide a link to the Creative Commons license, and indicate if changes were made.

\section{References}

Agnew, R. (2010). A general strain theory of terrorism. Theoretical Criminology, 14(2), 131-154.

Akers, R. (2010). Religion and crime. The Criminologist, 36(6), 1-6.

Alexander, H. (2015). What is going wrong in France's prisons? The Telegraph 17/01/15.

Andre, V., \& Harris-Hogan, S. (2013). Mohamed Merah: From petty criminal to neojihadist. Politics Religion and Ideology, 14(2), 307-319.

Barras, A. (2013). Sacred Laïcité and the politics of religious resurgence in France: Whither religious Pluralism? Mediterranean Politics, 18(2), 276-293.

Bauman, Z. (2006). Liquid fear. Cambridge: Polity Press.

BBC News. (2015). Paris attacks: Suspects' profiles. January 12.

Beaud, S. (2015). French sociologists debate the killings at Charlie Hebdo. Global Dialogue, 5(2), 13-15.

Beck, U. (2015). Emancipatory catastrophism: What does it mean to climate change and risk society? Current Sociology, 63(1), 75-88.

Bell, D. (1979). The cultural contradictions of capitalism 2/e. London: Heinemann.

Bhui, K., Everitt, B., \& Jones, E. (2014). Might depression, psychosocial adversity, and limited social assets explain vulnerability to and resistance against violent radicalisation? PLoS One, 9(9), 1-110.

Bielefeldt, H. (2015). Special rapporteur on freedom of religion and belief, report on preventing violence in the name of religion, Geneva: UN Human Rights Council, report A/HRC/28/66.

Billig, P., \& Stalne, K. (2012). Learning from the unfathomable: An analysis of anders behring breivik. Integral Review, 7(2), 150-160.

Body-Gendrot, S. (2010). Police marginality, racial logics and discrimination in the banlieues of France. Ethnic and Racial Studies, 33(4), 656-674.

Body-Gendrot, S. (2012). Globalization, fear and insecurity. London; Palgrave: MacMillan.

Braithwaite, J. (1989). Crime, shame and reintegration. Cambridge: Cambridge University Press.

Camilleri, R. (2012). Impact of counter-terrorism on communities: France background report. London: Institute for Strategic Dialogue.

Chrisafis, A. (2015). Profiles: Key suspects in Paris attacks. The Guardian. January 9.

Cottee, S. (2011). Jihadism as a subcultural response to social strain: Extending Marc Sageman's 'bunch of guys" Thesis. Terrorism and Political Violence, 23, 730-751.

Cottee, S. (2014). We need to talk about Mohammad: Criminology, theistic violence and the murder of Theo Van Gogh. British Journal of Criminology, 54(6), 981-1001.

Cretenot, M., \& Liaros, B. (2013). Prison conditions in France. Rome: European Prison Observatory.

Dalgaard-Nielsen, A. (2010). Violent radicalization in Europe: What we know and what we do not know. Studies in Conflict \& Terrorism, 33(9), 797-814.

Fassin, D. (2011). The trace; violence, truth and the politics of the body. Social Research, 78(2), 281-298.

Fassin, D. (2013). Enforcing order. Cambridge: Polity.

Fassin, D. (2016). Short cuts. London review of books 38(5) 3rd March. http://www.lrb.co.uk/v38/n05/ didier-fassin/short-cuts.

Gruenwald, J., Chemak, S., \& Freilich, J. D. (2013). Distinguishing 'loner' attacks from other domestic extremist violence: A comparison of far-right homicide incident and offender characteristics. Criminology and Public Policy, 12(1), 65-91.

Hallsworth, S., \& Lea, J. (2011). Reconstructing Leviathan: Emerging contours of the security state. Theoretical Criminology, 15(2), 141-158.

Hamm, M. (2009). Prison islam in the age of sacred terror. British Journal of Criminology, 49(5), 667-685.

Hedges, C. (2015). A message from the dispossessed. The Guardian, January 11th.

Irish Times. (2015). Profile: Amedy Coulibaly, the kosher supermarket gunman. January 9.

Jenks, C. (2003). Transgression. London: Sage.

Khan, F., \& Mythen, G. (2015). Double standards and speech deficits: What is sayable for British muslims after Paris? Sociological Research Online, 20(3): http://www.socresonline.org.uk/20/3/2.html. doi:10. 5153 /sro.3759.

Khosrokhavar, F. (2013). Radicalization in prison: The French case. Politics Religion and Ideology, 14(2), 284-306. 
Kreuger, A., \& Maleckova, J. (2003). Education, poverty and terrorism: Is there a causal connection? The Journal of Economic Perspectives, 17(4), 119-144.

Lee, J. A. (1981). Some structural aspects of police deviance in relations with ethnic minority groups. In C. Shearing (Ed.), Organisational police deviance. Toronto: Butterworth.

Meichtry, S. (2015). Paris attacker amedy coulibaly's path to terror. Wall Street Journal. January 14.

Mullins, C., \& Young, J. (2012). Cultures of violence and terrorism: A test of the legitimating-habituation model. Crime and Delinquency, 58(1), 28-56.

Murray, G. (2006). France: The riots and the republic. Race and Class, 47(4), 26-45.

Pape, R. (2006). Dying to win. New York: Random House.

Post, J. M. (2007). The mind of the terrorist. New York: Palgrave-Macmillan.

Routledge, C., \& Arndt, J. (2008). Self-sacrifice as self-defence: Mortality salience increases efforts to affirm a symbolic immortal self at the expense of the physical. European Journal of Social Psychology, 38(3), 531-541.

Sageman, M. (2007). Leaderless jihad. Terror networks in the twenty-first century. Philadelphia: University of Pennsylvania.

Sampson, R. J., \& Laub, J. H. (1993). Crime in the making: Pathways and turning points through life. Cambridge: Harvard University Press.

Schmid, A. P. (2013). Radicalisation, De-radicalisation, counter-radicalisation: A conceptual discussion and literature review (ICCT Research Paper). The Hague: International Center for Counter-terrorism.

Spalek, B. (2006). Crime victims. London: Palgrave.

Tivalli, V., Brezina, T., \& Bernhardt, M. (2013). With god on my side: The paradoxical relationship between religious belief and criminality among hardcore street offenders. Theoretical Criminology, 17(1), 49-69.

Wacquant, L. (2009). Punishing the poor. London: Duke University Press.

Walklate, S., \& Mythen, G. (2015). Contradictions of terrorism: Security, risk and resilience. London: Routledge.

Wiktorowicz, Q. (2005). A genealogy of radical islam. Studies in Conflict and Terrorism, 28, 75-97.

Young, J. (2011). The criminological imagination. Cambridge: Polity. 